\title{
The influence of multicomponent fertilizers on the concentration of potassium in perennial ryegrass (Lolium perenne L.)
}

\author{
Beata Draszawka - Bołzan \\ Faculty of Biology, University of Szczecin, 13 Waska Street, 71-415 Szczecin, Poland \\ E-mail address: atkadb@o2.pl
}

\begin{abstract}
A pot experiment on an acid brown soil was conducted in 1998-2001. Three multicomponent fertilizers were applied: Polifoska 8, Polifoska 15 and Polimag 306, Travit at the rates of 0.5; 1.0; and $1.5 \mathrm{~g} \mathrm{~N}$ per pot. The total forms of potassium were determined in dry matter of perennial ryegrass with the use of ASA method. The contents of these elements were higher in the fertilized variants as compared to the control. No significant differences were found among the contents of investigated elements compared in plants treated with different multicomponent fertilizers. The chemical analyses indicated that increasing rates of the fertilizers applied enhanced the contents of potassium. In the content of potassium in dry matter of perennial ryegrass (Lolium perenne L.) the Polifoska 8 it ranged from $3.49-4.92 \%$. In the content of potassium in dry matter of perennial ryegrass (Lolium perenne L.) the Polifoska 15 it ranged from 4.29-4.86\%. In the content of potassium in dry matter of perennial ryegrass (Lolium perenne L.) the Polimag 306 it ranged from 4.07-5.17\%. In the content of potassium in dry matter of perennial ryegrass (Lolium perenne L.) the Travit it ranged from 3.84-4.73\%. The content of potassium in perennial ryegrass (Lolium perenne L.) was mostly higher on objects may receive farm manures fertilisers compared to the control object.
\end{abstract}

Keywords: soil; mineral fertilizer; the contents potassium

\section{INTRODUCTION}

Urbanization is the cause of many changes which is taking place in the environment, including those found in the catchment [4-12,22-26].

With this in mind, an important issue is the proper protection of water reservoirs and also taking action to counter the adverse effects of human activities on the natural environment, including water tanks [4-14,19,31].

The problem of soil heavy metals pollution occurs in Poland locally and applies first of all industrialized areas, but in some areas, in the vicinity of the former or current sources of emissions, soil sometimes exhibit a significant degree of pollution [1-14,19,21-27].

Heavy metals occur as contaminants of agricultural and industrial area. Their longlasting results in the accumulation of surface soil layers in the deposition and migrate deeper into the soil profile, right down to the groundwater [20-28,30-34] . 
Heavy metals in soils may constitute a potential source of danger for plants and for groundwater, and consequently can be incorporated into the food chain [20-30]. Download trace of contaminated soils by plants often exceeds their physiological demand, which causes an excess of these elements in soils can act phytotoxic [19,21].

\section{EXPERIMENTAL}

A pot experiment on an acid brown soil was conducted in 1998-2001. Three multicomponent fertilizers were applied: Polifoska 8, Polifoska 16 and Polimag 306, at the rates of $0.5 ; 1.0$; and $1.5 \mathrm{~g} \mathrm{~N}$ per pot. The total forms of potassium were determined in dry matter of perennial ryegrass with the use of ASA method. The contents of these elements were higher in the fertilized variants as compared to the control. No significant differences were found among the contents of investigated elements compared in plants treated with different multicomponent fertilizers [19-23]. The soil on Which experience has been Carried out to qualified valuation class IVa. Test plant was perennial ryegrass (Lolium perenne L.). After the growth of biological material (Lolium perenne L.), and the mixture mineralization nitric and perchloric acids determined potassium.

Table 1. Characteristics of experimental soils.

\begin{tabular}{|c|c|c|c|c|c|}
\hline \multirow{2}{*}{ Properties of soil } & \multicolumn{5}{c|}{ Year } \\
\cline { 3 - 6 } & 1998 & 1999 & 2000 & 2001 \\
\hline \multicolumn{2}{|c|}{ No. of trials } & I,II & III,IV & V,VI & VII,VIII \\
\hline \multirow{3}{*}{$\begin{array}{c}\text { Fraction } \\
(\%)\end{array}$} & $1.0-0.1 \mathrm{~mm}$ & 64 & 62 & 67 & 63 \\
\cline { 2 - 6 } & $0,1-0.02 \mathrm{~mm}$ & 25 & 26 & 25 & 27 \\
\cline { 2 - 6 } & $<0.02 \mathrm{~mm}$ & 18 & 16 & 17 & 17 \\
\hline \multicolumn{2}{|c|}{ Soil symbol } & pgm & pgm & pgl & pgm \\
\hline \multicolumn{2}{|c|}{ C org. $(\%)$} & 0.61 & 0.57 & 0.64 & 0.65 \\
\hline \multirow{2}{*}{$\mathrm{pH}(1 \mathrm{~mol} \cdot \mathrm{dm}-3 \mathrm{KCl})$} & 4,2 & 4,5 & 4,3 & 4,5 \\
\hline \multirow{3}{*}{$\begin{array}{c}\text { Content } \\
(\mathrm{mg} \cdot \mathrm{kg}-1)\end{array}$} & $\mathrm{P}_{2} \mathrm{O}_{5}$ & 147 & 142 & 145 & 143 \\
\cline { 2 - 6 } & $\mathrm{K}_{2} \mathrm{O}$ & 121 & 115 & 106 & 119 \\
\cline { 2 - 6 } & $\mathrm{Mg}^{2}$ & 42 & 40 & 43 & 38 \\
\hline
\end{tabular}

\section{RESULTS AND DISCUSSION}

Results of the content of potassium in dry matter of perennial ryegrass (Lolium perenne L.) in Tables 2 to 5 . 
Table 2. The content of potassium in dry matter of perennial ryegrass (Lolium perenne L.) (1999-2001) [\%] - Polifoska 8.

\begin{tabular}{|c|c|c|c|c|c|}
\hline \multirow{2}{*}{$\begin{array}{l}\text { Fertilizers } \\
\text { compared }\end{array}$} & \multirow{2}{*}{ Doses } & \multicolumn{4}{c|}{ Potassium } \\
\cline { 3 - 6 } & & I & II & III & Mean \\
\hline \multicolumn{2}{|c|}{ Control } & 2.52 & 2.59 & 3.87 & 2.99 \\
\hline \multirow{2}{*}{ Polifoska 8} & $2 \mathrm{~d}$ & 3.69 & 3.85 & 4.43 & 3.99 \\
\cline { 3 - 6 } & $3 \mathrm{~d}$ & 3.49 & 3.73 & 4.67 & 3.96 \\
\hline \multicolumn{2}{|c|}{ Mean } & 3.57 & 3.85 & 4.67 & 4.03 \\
\hline \multicolumn{2}{|c|}{ Minimum } & 3.49 & 3.73 & 4.43 & - \\
\hline \multicolumn{2}{|c|}{ Maximum } & 3.69 & 3.97 & 4.92 & - \\
\hline \multicolumn{2}{|c|}{ Standard deviation } & 0.93 & 0.89 & 1.13 & - \\
\hline \multicolumn{2}{|c|}{ Mediana } & 1.12 & 1.06 & 0.86 & - \\
\hline \multicolumn{2}{|c|}{ Coefficient of variation } & 6.3 & 9.2 & 7.9 & - \\
\hline
\end{tabular}

Explanations: $1 \mathrm{~d}-$ doses $-0.5 \mathrm{gN}, 2 \mathrm{~d}-$ doses $-0.5 \mathrm{gN}, 3 \mathrm{~d}-$ doses $-0.5 \mathrm{gN}$.

Table 3. The content of potassium in dry matter of perennial ryegrass (Lolium perenne L.) (1999-2001) [\%] - Polifoska 15.

\begin{tabular}{|c|c|c|c|c|c|}
\hline \multirow{2}{*}{$\begin{array}{l}\text { Fertilizers } \\
\text { compared }\end{array}$} & \multirow{2}{*}{ Doses } & \multicolumn{3}{|c|}{ Potassium } & \\
\cline { 3 - 6 } & & I & II & III & Mean \\
\hline \multicolumn{2}{|c|}{ Control } & 4.72 & 4.47 & 3.85 & 4.35 \\
\hline \multirow{2}{*}{ Polifoska 15 } & $2 \mathrm{~d}$ & 4.59 & 4.29 & 4.73 & 4.54 \\
\cline { 3 - 6 } & $3 \mathrm{~d}$ & 4.41 & 4.36 & 4.86 & 4.54 \\
\hline \multicolumn{2}{|c|}{ Mean } & 4.46 & 4.45 & 4.70 & 4.54 \\
\hline \multicolumn{2}{|c|}{ Minimum } & 4,38 & 4.29 & 4.52 & - \\
\hline \multicolumn{2}{|c|}{ Maximum } & 4.59 & 4.69 & 4.86 & - \\
\hline \multicolumn{2}{|c|}{ Standard deviation } & 0.97 & 0.91 & 0.69 & - \\
\hline \multicolumn{2}{|c|}{ Mediana } & 0.78 & 0.93 & 0.87 & - \\
\hline \multicolumn{2}{c|}{ Coefficient of variation } & 8.3 & 10.1 & 9.5 & - \\
\hline
\end{tabular}

Explanations: $1 \mathrm{~d}-$ doses $-0.5 \mathrm{gN}, 2 \mathrm{~d}-$ doses $-0.5 \mathrm{gN}, 3 \mathrm{~d}-$ doses $-0.5 \mathrm{gN}$. 
Table 4. The content of potassium in dry matter of perennial ryegrass (Lolium perenne L.) (1999-2001) [\%] - Polimag 306.

\begin{tabular}{|c|c|c|c|c|c|}
\hline \multirow{2}{*}{$\begin{array}{l}\text { Fertilizers } \\
\text { compared }\end{array}$} & \multirow{2}{*}{ Doses } & \multicolumn{3}{|c|}{ Potassium } & \\
\cline { 3 - 6 } & & I & II & III & Mean \\
\hline \multicolumn{2}{|c|}{ Control } & 4.61 & 4.89 & 4.38 & 4.63 \\
\hline \multirow{2}{*}{ Polimag 306 } & $2 \mathrm{~d}$ & 4.42 & 5.09 & 4.39 & 4,63 \\
\cline { 3 - 6 } & $3 \mathrm{~d}$ & 4.64 & 4.85 & 4.07 & 4,52 \\
\hline \multicolumn{2}{|c|}{ Mean } & 4.60 & 5.04 & 4.40 & - \\
\hline \multicolumn{2}{|c|}{ Minimum } & 4.42 & 4.85 & 4.07 & - \\
\hline \multicolumn{2}{|c|}{ Maximum } & 4.75 & 5.17 & 4.74 & - \\
\hline Standard deviation & 1.27 & 1.09 & 1.42 & - \\
\hline \multicolumn{2}{|c|}{ Mediana } & 1.14 & 1.72 & 1.81 & - \\
\hline Coefficient of variation & 10.4 & 9.7 & 11.5 & - \\
\hline
\end{tabular}

Explanations: $1 \mathrm{~d}-$ doses $-0.5 \mathrm{gN}, 2 \mathrm{~d}-$ doses $-0.5 \mathrm{gN}, 3 \mathrm{~d}-$ doses $-0.5 \mathrm{gN}$.

Table 5. The content of potassium in dry matter of perennial ryegrass (Lolium perenne L.) (1999-2001) [\%] - Travit.

\begin{tabular}{|c|c|c|c|c|c|}
\hline \multirow{2}{*}{$\begin{array}{l}\text { Fertilizers } \\
\text { compared }\end{array}$} & \multirow{2}{*}{ Doses } & \multicolumn{3}{|c|}{ Potassium } & \multirow[b]{2}{*}{ Mean } \\
\hline & & $\mathrm{I}$ & II & III & \\
\hline \multicolumn{2}{|c|}{ Control } & 4.61 & 4.19 & 3.64 & 3.17 \\
\hline \multirow{3}{*}{ Travit } & $1 d$ & 4.29 & 4.62 & 4.19 & 4.37 \\
\hline & $2 d$ & 3.84 & 4.59 & 3.95 & 4.13 \\
\hline & $3 d$ & 4.57 & 4.73 & 3.71 & 4.34 \\
\hline \multicolumn{2}{|c|}{ Mean } & 4.23 & 4.65 & 3.95 & - \\
\hline \multicolumn{2}{|c|}{ Minimum } & 3.84 & 4.59 & 3.71 & - \\
\hline \multicolumn{2}{|c|}{ Maximum } & 4.57 & 4.73 & 4.19 & - \\
\hline \multicolumn{2}{|c|}{ Standard deviation } & 0.93 & 1.27 & 0.72 & - \\
\hline \multicolumn{2}{|c|}{ Mediana } & 0.74 & 1.13 & 1.18 & - \\
\hline \multicolumn{2}{|c|}{ Coefficient of variation } & 10.2 & 11.7 & 9.1 & - \\
\hline
\end{tabular}

Explanations: $1 \mathrm{~d}-$ doses $-0.5 \mathrm{gN}, 2 \mathrm{~d}-$ doses $-0.5 \mathrm{gN}, 3 \mathrm{~d}-$ doses $-0.5 \mathrm{gN}$. 
The average potassium content in perennial ryegrass (Lolium perenne L.) sustainable compound fertilisers applied at all was higher compared to the control object (Table 2-5). Comparing the content of potassium in each swath slightly higher than the value found in the second and third cut. In the content of potassium in dry matter of perennial ryegrass (Lolium perenne L.) the Polifoska 8 it ranged from 3.49-4.92\%. In the content of potassium in dry matter of perennial ryegrass (Lolium perenne L.) the Polifoska 15 it ranged from 4.29-4.86\%. In the content of potassium in dry matter of perennial ryegrass (Lolium perenne L.) the Polimag 306 it ranged from 4.07-5.17\%. In the content of potassium in dry matter of perennial ryegrass (Lolium perenne L.) the Travit it ranged from 3.84-4.73\%.

The content of potassium in perennial ryegrass (Lolium perenne L.) was mostly higher on objects may receive farm manures fertilisers compared to the control object.

\section{CONCLUSIONS}

The content of potassium in perennial ryegrass (Lolium perenne L.) was mostly higher on objects may receive farm manures fertilisers compared to the control object. Differences in the potassium content of fertilisers applied between were insignificant.

1. In the content of potassium in dry matter of perennial ryegrass (Lolium perenne L.) the Polifoska 8 it ranged from 3.49-4.92\%.

2. In the content of potassium in dry matter of perennial ryegrass (Lolium perenne L.) the Polifoska 15 it ranged from 4.29-4.86 \%.

3. In the content of potassium in dry matter of perennial ryegrass (Lolium perenne L.) the Polimag 306 it ranged from 4.07-5.17\%.

4. In the content of potassium in dry matter of perennial ryegrass (Lolium perenne L.) the Travit it ranged from 3.84-4.73\%.

The content of potassium in perennial ryegrass (Lolium perenne L.) was mostly higher on objects may receive farm manures fertilisers compared to the control object.

\section{References}

[1] Azarmi R., Giglou M. T., Taleshmikail R. D., Afr. J. Biotechnol. 7(14) (2008) $2397-2401$.

[2] Anke M., Kolloquien des Instituts für Pflanzenernảhrung. Jena 2 (1987) 110-111.

[3] Broos K., Beyens H., Smolders E., Soil Biology \& Biochemistry 37 (2005) 573-579.

[4] Cyraniak E., Daniszewski P., Draszawka - Bołzan B., International Letters of Chemistry, Physics and Astronomy 5 (2012) 88-95

[5] Cyraniak E., Daniszewski P., Draszawka - Bołzan B., International Letters of Chemistry, Physics and Astronomy 5 (2012) 96-103.

[6] Daniszewski P., Ekologia i Technika 5 (2008) 211-214.

[7] Daniszewski P., Wiadomości Melioracyjne i Łąkarskie 4 (2008) 187-188, (Poland).

[8] Daniszewski P., International Letters of Chemistry, Physics and Astronomy 1 (2012) 13-16. 
[9] Daniszewski P., International Letters of Chemistry, Physics and Astronomy 2 (2012) $35-41$.

[10] Daniszewski P., International Letters of Chemistry, Physics and Astronomy 2 (2012) $42-45$.

[11] Daniszewski P., International Letters of Chemistry, Physics and Astronomy 2 (2012) 46-52.

[12] Daniszewski P., International Letters of Chemistry, Physics and Astronomy 4 (2012) 119-124.

[13] Daniszewski P., International Letters of Chemistry, Physics and Astronomy 5 (2012) 72-79.

[14] Daniszewski P., International Letters of Chemistry, Physics and Astronomy 5 (2012) 80-87.

[15] Daniszewski P., Konieczny R., International Letters of Chemistry, Physics and Astronomy 4 (2013) 91-97.

[16] Daniszewski P., Konieczny R., International Letters of Chemistry, Physics and Astronomy 4 (2013) 98-104.

[17] Daniszewski P., Konieczny R., International Letters of Chemistry, Physics and Astronomy 5 (2013) 66-75.

[18] Daniszewski P., Konieczny R., International Letters of Chemistry, Physics and Astronomy 5 (2013) 86-96.

[19] Daniszewski P., International Letters of Chemistry, Physics and Astronomy 7(1) (2013) 60-66.

[20] Daniszewski P., International Letters of Chemistry, Physics and Astronomy 7(1) (2013) 67-72.

[21] Desai V. R., Sabale R. N., Raundal P. V., Agric. Univ. 24(3) (1999) 273-275 .

[22] Japony M., Young S. D. E., J. Soil Sci. 45 (1994) 59-70.

[23] Kabata-Pendias A., Zesz. Nauk. Kom. PAN Człowiek i środowisko 21 (1998) 9-17.

[24] Kabata-Pendias A., Zesz. Nauk. Kom. PAN Człowiek i środowisko 33 (2000) 1-18.

[25] Kabata-Pendias A., Pendias H., CRC Press, Boca Raton, Fl, USA (2001) 413.

[26] Kalembasa S., Symanowicz B., Chem. Engin. A. 17(7) (2010) 757-764.

[27] Nowak W., Draszawka-Bołzan B., Agricultura 84 (2000)363-366.

[28] Parthasarathi K., Balamurugan M., Ranganathan L. S., Iran. J. Environ. Health Sci. Eng. 5 (1) (2008) 51-58.

[29] Patil S. L., Sheelavantar M. N., Annals Agric. Res. 21(21) (2000) 32-36.

[30] Spiak Z., Romanowska M., Radoła J., Chemistry for Agricultulture 5 (2004) 181-186.

[31] Symanowicz B., Acta Sci. Pol. Agricult. 4(2) (2005) 83-92. 
[32] Symanowicz B., Appel Th., Kalembasa S., Polish J. Soil Sci. XXXVII(1) (2004) 11-20.

[33] Symanowicz B., Kalembasa S., Fragm. Agron. 27(1) (2010) 177-185.

[34] Trabelsi D., Pini F., Aouani M. E., Bazzicalupo M., Mengoni A., Letters in Applied Microbiology 48 (2009) 355-361. 